\title{
Kecemasan dan status gizi berhubungan dengan lama rawat inap pada pasien jantung di RSUD Jenderal Ahmad Yani, Metro, Lampung
}

\author{
Nutritional status and anxiety associated with the length of stay in heart failure patients at Jenderal \\ Ahmad Yani General Hospital, Metro, Lampung
}

Eva Nurlindayanti ${ }^{1}$, Susetyowati ${ }^{2}$, Probosuseno $^{3}$, Retno Pangastuti ${ }^{4}$

\begin{abstract}
Background: Anxiety is one of the most common psychological problem occured in hospitality patient. The prevalence of anxiety in chronic heart failure patients was 11-45\%. Anxiety in heart failure patients could worsening patient's condition that lead to increased ischemic event, morbidity, negative effects on quality of life, and mortality. Despite anxiety, nutritional status is also one of the most important thing in mantaining patient's health. Malnutrition has association with increased morbidity, complication, length of stay (LOS), medical therapy, and hospital fees.

Objectives: To know the impact of nutritional status and anxiety on LOS in chronic heart failure patients at Jenderal Ahmad Yani General Hospital, Metro, Lampung.

Methods: This was an observational quantitative study with cohort prospective design. The research was conducted on July 2014. Subjects were 70 patients who full filled the inclusive requirement, patients with anxiety as exposed group and patients without anxiety as non-exposed group. Anxiety was assessed with Hospital Anxiety and Depression Scale (HADS), while nutritional status was assessed by upper-arm circumference. Data were analyzed with chi-square and logistic regression test.

Results: Bivariate test showed that there was significant association between anxiety with LOS $(p<0.05)$. Subjects without anxiety tended to have shorter LOS than that of with anxiety $(R R=5.5)$. There was significant association between nutritional status and LOS $(p<0.05)$. Subjects with normal nutritional status tended to have shorter LOS than that of with undernutrition $(R R=2.28)$. Multivariate test showed that there was an association between anxiety and LOS $(p<0.05)$ with OR=11.22.

Conclusions : There was an association between anxiety and LOS. Patients without anxiety had shorter LOS than that of with anxiety. There was association between nutritional status and LOS. Patients with normal nutritional status had shorter LOS than undernutrition patients.
\end{abstract}

KEYWORDS: anxiety, heart failure patients, length of stay, nutritional status

\begin{abstract}
ABSTRAK
Latar belakang: Kecemasan merupakan salah satu masalah psikologi yang banyak dialami oleh pasien di rumah sakit. Prevalensi kecemasan pada pasien gagal jantung sekitar 11-45\%. Kecemasan pada penyakit jantung yang tidak teratasi dapat berakibat pada penurunan kualitas hidup pasien, peningkatan iskemik, dan kejadian masuk rumah sakit berulang yang pada akhirnya akan meningkatkan mortalitas. Selain kecemasan, status gizi juga menjadi salah satu faktor penting dalam menunjang kesehatan pasien. Malnutrisi berhubungan dengan peningkatan kesakitan, komplikasi, lama rawat inap, terapi medis, dan biaya perawatan rumah sakit.
\end{abstract}

\footnotetext{
${ }^{1}$ RSUD Jenderal Ahmad Yani, Metro, Jl. Jend. A. Yani No 13 Metro Pusat, Kota Metro, Lampung, e-mail: eva.nurlindayanti@gmail. com

${ }^{2}$ Program Studi Gizi Kesehatan, Fakultas Kedokteran Universitas Gadjah Mada, Jl. Farmako, Sekip Utara Yogyakarta 55281, e-mail:susetyowati2000@yahoo.com

${ }^{3}$ Spesialis Penyakit Dalam Konsultan Geriatri di RSUP Dr. Sardjito, JI. Kesehatan No 1, Yogyakarta 55281.

${ }^{4}$ Instalasi Gizi RSUP Dr. Sardjito, JI. Kesehatan No 1, Yogyakarta 55281.
} 
Tujuan: Mengetahui pengaruh status kecemasan dan status gizi saat masuk terhadap lama rawat inap pada pasien jantung di RSUD Jenderal Ahmad Yani, Metro, Lampung.

Metode: Penelitian ini merupakan penelitian observasional kuantitatif dengan rancangan cohort prospective. Penelitian dilakukan pada bulan Juli 2014. Subjek penelitian adalah 70 pasien jantung di RSUD Jenderal Ahmad Yani Metro yang memenuhi kriteria inklusi, dengan kelompok terpapar adalah pasien jantung dengan kecemasan dan pasien jantung tanpa kecemasan sebagai kelompok tidak terpapar. Status kecemasan diukur dengan kuesioner Hospital Anxiety and Depression Scale (HADS), sedangkan status gizi diukur dengan lingkar lengan atas. Data dianalisis dengan uji chi-square dan uji regresi logistik.

Hasil: Hasil uji bivariat menunjukkan adanya hubungan bermakna antara status kecemasan dengan lama rawat inap $(p<0,05)$. Subjek tanpa kecemasan cenderung memiliki lama rawat yang lebih pendek $(R R=5,5)$. Ada hubungan yang bermakna antara status gizi dengan lama rawat inap $(p<0,05)$. Subjek dengan status gizi baik cenderung memiliki lama rawat yang lebih pendek daripada subjek dengan status gizi kurang $(R R=2,28)$. Hasil uji multivariat menunjukkan adanya hubungan bermakna antara status kecemasan dengan lama rawat inap $(p<0,05)$ dengan nilai $O R=11,22$.

Kesimpulan: Ada hubungan bermakna antara tingkat kecemasan dengan lama rawat inap. Pasien tanpa kecemasan memiliki lama rawat yang lebih pendek dari pada pasien jantung dengan kecemasan. Ada hubungan bermakna antara status gizi dengan lama rawat inap. Pasien jantung berstatus gizi baik memiliki lama rawat yang lebih pendek daripada pasien jantung berstatus gizi kurang.

KATA KUNCI: kecemasan, pasien jantung, lama rawat, status gizi

\section{PENDAHULUAN}

Kecemasan merupakan salah satu masalah psikologi yang banyak dialami oleh pasien di rumah sakit. Pada pasien gagal jantung, tingkat kecemasan juga umum terjadi (1), baik kecemasan tingkat ringan, sedang, hingga tingkat berat (2). Frekuensi kecemasan pada penderita gagal jantung cukup tinggi, yaitu sebesar $74 \%$ (3). Pada penelitian lain disebutkan bahwa prevalensi kecemasan pada pasien gagal jantung sekitar $11-45 \%$ (4). Kecemasan pada penyakit jantung yang tidak teratasi ini dapat memberikan akibat buruk pada pasien seperti penurunan kualitas hidup pasien, peningkatan iskemik, dan kejadian masuk rumah sakit berulang yang pada akhirnya akan meningkatkan mortalitas $(1,4,5)$.

Penyakit jantung merupakan salah satu dari sepuluh besar penyakit di RSUD Jenderal Ahmad Yani, Metro, Lampung. Kejadian gagal jantung ini cenderung mengalami peningkatan tiap tahunnya. Gagal jantung menempati urutan tujuh yaitu 3,23\% dari 14.232 pasien pada tahun 2012 atau sekitar 459 pasien dalam setahun (6).

Status gizi menjadi salah satu faktor penting dalam menunjang kesehatan seseorang. Malnutrisi merupakan salah satu faktor risiko pada lama rawat inap pasien di rumah sakit. Status gizi pasien yang kurang atau buruk akan meningkatkan lama rawat inap pasien di rumah sakit (7). Beberapa penelitian telah menyebutkan adanya kaitan parameter gizi dengan lama rawat inap, namun belum banyak yang meneliti bagaimana kecemasan dan status gizi dalam mempengaruhi lama rawat pasien di rumah sakit. Penelitian ini bertujuan untuk mengetahui pengaruh status kecemasan dan status gizi saat masuk terhadap lama rawat pada pasien jantung terutama di RSUD Jenderal Ahmad Yani, Metro, Lampung.

\section{BAHAN DAN METODE}

Penelitian ini merupakan penelitian observasional kuantitatif dengan rancangan cohort prospective. Jumlah subjek penelitian sebanyak 70 orang dengan kelompok terpapar (exposed) yaitu subjek dengan kecemasan yang berjumlah 35 orang dan kelompok tidak terpapar (non-exposed) adalah subjek penelitian tidak cemas yang berjumlah 35 orang. Penelitian ini dilaksanakan di ruang rawat inap kelas perawatan I, II, dan III RSUD Jenderal Ahmad Yani, Metro, Lampung. Pengumpulan data penelitian dilakukan pada bulan Juli 2014. Subjek penelitian harus memenuhi kriteria inklusi, yaitu: 
pasien baru masuk rumah sakit/dirawat, berumur $>18$ tahun, kesadaran baik selama dirawat, bersedia berpartisipasi dalam penelitian. Kriteria eksklusi yaitu: pasien pulang atas permintaan sendiri, pasien dengan komplikasi kanker, dan pasien penyakit jantung tiroid.

Status kecemasan diukur dengan menggunakan kuesioner Hospital Anxiety and Depression Scale (HADS), yang terdiri dari 7 pertanyaan mengenai kecemasan pasien. Tiap pertanyaan memiliki empat kemungkinan jawaban yang bernilai 0 hingga 3 , dengan total skor 21 poin. Status kecemasan ini dibedakan menjadi dua kelompok yaitu kelompok tidak cemas dan kelompok cemas. Seseorang dikatakan cemas apabila skor kecemasan $\geq 11$.

Status gizi diukur dengan mengukur lingkar lengan atas (LLA). Status gizi dikelompokkan menjadi dua yaitu status gizi baik dan kurang. Kriteria status gizi dibedakan berdasarkan jenis kelamin, yaitu kurang jika LLA pada laki-laki $<26,1$ $\mathrm{cm}$ dan perempuan $<23,5 \mathrm{~cm}$, status gizi baik apabila LLA pada laki-laki $\geq 26,1 \mathrm{~cm}$ dan perempuan $\geq 23,5 \mathrm{~cm}$.

Lama rawat inap diperoleh dari catatan rekam medis pasien berdasarkan tanggal masuk dan tanggal keluar pasien dengan cara tanggal keluar dikurangi tanggal masuk rumah sakit. Penentuan standar lama rawat inap berdasarkan rata-rata lama rawat inap rumah sakit RSUD Jenderal Ahmad Yani, Metro, Lampung pada tahun 2011 dan 2012 yaitu 4 hari. Pada penelitian ini ditentukan cut off point lama rawat inap adalah 4 hari. Dikatakan lama rawat pendek apabila lama rawat $<4$ hari dan lama rawat panjang jika lama rawat $\geq 4$ hari.

Penelitian ini dilakukan dengan melalui proses kelaikan etik terlebih dahulu dan dilaksanakan berdasarkan etika penelitian. Proposal penelitian diajukan pada Komite Etik Penelitian Kedokteran Kesehatan Universitas Gadjah Mada untuk mendapatkan ethical clearance dengan nomor Ref: KE/FK/727/EC. Kemudian dilakukan permintaan perizinan pada tempat penelitian bersama dengan surat izin penelitian dari Program Studi IImu Kesehatan Masyarakat Fakultas Kedokteran Universitas Gadjah Mada.
HASIL

\section{Karakteristik subjek penelitian}

Usia rata-rata subjek yang diambil dalam penelitian ini adalah 57,09 tahun (SD $\pm 12,81$ tahun) dengan usia minimum 30 tahun dan usia maksimum 84 tahun. Pasien dengan jenis kelamin laki-laki berjumlah 33 orang dan pasien perempuan berjumlah 37 orang. Sebagian besar subjek bekerja sebagai buruh, ibu rumah tangga ataupun tidak bekerja $(34,3 \%)$, memiliki tingkat keparahan penyakit sedang-berat $(77,1 \%)$, dan memiliki riwayat masuk rumah sakit antara $1-2$ kali $(71,4 \%)$ (Tabel 1).

Tabel 1. Distribusi responden berdasarkan karakteristik

\begin{tabular}{lcc}
\hline \multicolumn{1}{c}{ Karakteristik } & $\mathbf{n = 7 0}$ & $\mathbf{\%}$ \\
\hline Umur & & \\
$\quad$ 18-59 tahun & 40 & 57,1 \\
$\quad$ >59 tahun & 30 & 42,9 \\
Jenis kelamin & & \\
$\quad$ Laki-laki & 33 & 47,1 \\
$\quad$ Perempuan & 37 & 52,9 \\
Jenis pekerjaan & & \\
$\quad$ Petani & 14 & 20,0 \\
$\quad$ Wiraswasta & 15 & 21,4 \\
$\quad$ PNS/Pensiunan & 17 & 24,3 \\
$\quad$ Lain-lain (Buruh, Ibu Rumah & 24 & 34,3 \\
$\quad$ Tangga, Tidak bekerja) & & \\
Diagnosa & & \\
$\quad$ DC & \\
$\quad$ CAD/STEMI/N-STEMI** & 30 & 42,9 \\
$\quad$ Lain-lain (HHD, AHD, OMI) ${ }^{* * *}$ & 18 & 25,7 \\
Riwayat masuk RS & 22 & 31,4 \\
$\quad$ 1 - 2 kali & & \\
$\quad$ >2 kali & 50 & 71,4 \\
\hline
\end{tabular}

Keterangan :

* DC (Decompensatio cordis)

** CAD (Coronary artery disease), STEMI (ST segment elevation myocardial infarction), N-STEMI (Non ST segment elevation myocardial infarction)

${ }^{* * *} \mathrm{HHD}$ (Hypertensive heart disease), AHD (Atherosclerotic heart disease), OMI (Old myocardial infarction)

\section{Kecemasan, status gizi, dan lama rawat}

Rata-rata skor kecemasan subjek penelitian sebesar 8,77 poin $(S D \pm 3,62)$. Skor kecemasan minimum sebesar 2 poin dan maksimum sebesar 15 poin. Hasil pengukuran skor kecemasan ini dikelompokkan menjadi dua kategori, yaitu pasien 
tanpa kecemasan (skor < 11) dan pasien dengan kecemasan (skor $\geq 11$ ) (Tabel 2). Jumlah subjek kategori tidak cemas dan cemas masing-masing berjumlah 35 orang.

Tabel 2. Rata-rata skor kecemasan pada subjek penelitian berdasarkan tingkat kecemasan

\begin{tabular}{ll}
\hline Tingkat kecemasan & $\begin{array}{c}\text { Rata-rata skor } \\
\text { kecemasan }\end{array}$ \\
\hline Tidak cemas & $5,63 \pm 2,22$ \\
Cemas & $11,91 \pm 1,15$ \\
\hline
\end{tabular}

Hasil rata-rata LLA subjek penelitian sebesar $26,17 \mathrm{~cm}(\mathrm{SD} \pm 4,53)$. Hasil pengukuran LLA ini kemudian dikelompokkan menjadi dua kategori status gizi, yaitu status gizi baik dan status gizi kurang. Dari 70 orang subjek yang diteliti, 38 orang $(54,3 \%)$ memiliki status gizi baik dan 32 orang $(45,7 \%)$ memiliki status gizi kurang. Rata-rata LLA berdasarkan status gizi dapat dilihat pada Tabel 3.

Lama rawat inap dalam penelitian ini dihitung berdasarkan tanggal keluar dikurangi tanggal masuk pasien ke rumah sakit. Lama rawat inap dibagi menjadi dua kategori yaitu pendek dan panjang. Lama rawat pendek apabila lama rawat inap pasien kurang dari empat hari, sedangkan lama rawat panjang apabila lama rawat lebih dari atau sama dengan empat hari. Rata-rata lama rawat seluruh subjek penelitian ini adalah 4,13 hari $(S D \pm 1,71)$ dengan hari rawat terpendek selama 2 hari dan hari rawat terpanjang selama 10 hari. Jumlah subjek penelitian dengan lama rawat pendek sebanyak 26 orang $(37,1 \%)$ dan jumlah subjek dengan lama rawat panjang sebanyak 44 orang $(62,95 \%)$.

Tabel 3. Rata-rata LLA (lingkar lengan atas) subjek penelitian berdasarkan status gizi

\begin{tabular}{lc}
\hline \multicolumn{1}{c}{ Status gizi } & Rata-rata LLA \\
\hline Baik & $29,23 \pm 3,54$ \\
Kurang & $22,53 \pm 2,35$ \\
\hline
\end{tabular}

Tabel 4. Rata-rata lama rawat inap

\begin{tabular}{lc}
\hline \multicolumn{1}{c}{ Lama rawat } & Rata-rata lama rawat (hari) \\
\hline Pendek & $2,54 \pm 0,508$ \\
Panjang & $5,04 \pm 1,453$ \\
\hline
\end{tabular}

Pengaruh status kecemasan dan status gizi terhadap lama rawat

Tabel 5 memperlihatkan hasil rata-rata lama rawat inap pasien yang cemas dan tidak cemas. Nilai tersebut masing-masing adalah 4,74 dan 3,51. Ada perbedaan sebesar 1,23 poin. Perbedaan ini dapat membuktikan bahwa di antara kedua kelompok tersebut memiliki lama rawat inap yang berbeda karena nilai $p$ yang diperoleh berdasarkan uji statistik sebesar $0,001(p<0,05)$. Hal ini menunjukkan bahwa ada pengaruh antara status kecemasan terhadap lama rawat inap.

Begitupula dengan hasil uji chi-square yang menunjukkan adanya hubungan antara status kecemasan dengan lama rawat inap yang ditunjukkan dengan nilai $p=0,001 \quad(p<0,05)$. Berdasarkan hasil uji regresi logistik antara variabel status kecemasan dengan lama rawat inap, diperoleh nilai $R R$ sebesar 2,385 (Tabel 6).

Tabel 5. Hasil uji beda rata-rata lama rawat inap antara variabel status kecemasan dan status gizi

\begin{tabular}{llcc}
\hline \multicolumn{1}{c}{ Variabel } & N & $\begin{array}{c}\text { Mean lama } \\
\text { rawat inap (hari) }\end{array}$ & $\mathbf{p}$ \\
\hline $\begin{array}{l}\text { Status kecemasan } \\
\quad\end{array}$ & & & \\
$\quad$ Tidak cemas & 35 & $3,51( \pm 1,63)$ & $0,001^{*}$ \\
$\quad$ Cemas & 35 & $4,74( \pm 1,58)$ & \\
$\begin{array}{l}\text { Status gizi } \\
\quad \text { Baik }\end{array}$ & 38 & $3,79( \pm 1,70)$ & $0,044^{*}$ \\
$\quad$ Kurang & 32 & $4,53( \pm 1,67)$ & \\
\hline
\end{tabular}

* Signifikan $(p<0,05)$

Tabel 5 menunjukkan hasil rata-rata lama rawat inap pasien dengan status gizi baik dan kurang. Nilai tersebut masing-masing adalah 3,79 dan 4,53. Ada perbedaan sebesar 0,74 poin. Perbedaan ini dapat membuktikan bahwa di antara kedua kelompok yaitu kelompok status gizi baik dan kelompok status gizi kurang memiliki lama rawat inap yang berbeda karena nilai $p$ yang diperoleh berdasarkan uji statistik sebesar 0,044 $(p<0,05)$.

Begitupula dengan hasil uji chi-square yang menunjukkan adanya hubungan antara status gizi dengan lama rawat inap dengan nilai $p=0,015(p<0,05)$. Hal ini menunjukkan bahwa ada pengaruh antara status gizi terhadap lama rawat 
Tabel 6. Hasil uji chi-square dan regresi logistik antara kecemasan dan status gizi terhadap lama rawat inap

\begin{tabular}{|c|c|c|c|c|c|c|c|c|}
\hline & \multicolumn{4}{|c|}{ Lama rawat inap } & \multirow{2}{*}{\multicolumn{2}{|c|}{ Total }} & \multirow{3}{*}{$\mathbf{p}$} & \multirow{3}{*}{$\begin{array}{c}\text { RR } \\
(95 \% \mathrm{Cl})\end{array}$} \\
\hline & \multicolumn{2}{|c|}{ Panjang } & \multicolumn{2}{|c|}{ Pendek } & & & & \\
\hline & $\mathbf{n}$ & $\%$ & $\mathbf{n}$ & $\%$ & $n$ & $\%$ & & \\
\hline \multicolumn{9}{|c|}{ Status kecemasan } \\
\hline Cemas & 31 & 88,6 & 4 & 11,4 & 35 & 100 & $0,001^{*}$ & 2,385 \\
\hline Tidak cemas & 13 & 37,1 & 22 & 62,9 & 35 & 100 & & $(1,525-3,729)$ \\
\hline \multicolumn{9}{|l|}{ Status gizi } \\
\hline Kurang & 25 & 78,1 & 7 & 21,9 & 32 & 100 & $0,015^{*}$ & 1,563 \\
\hline Baik & 19 & 50,0 & 19 & 50,0 & 38 & 100 & & $(1,082-2,255)$ \\
\hline
\end{tabular}

* Signifikan $(p<0,05)$

inap (Tabel 6). Berdasarkan hasil uji regresi logistik antara variabel status gizi dengan lama rawat inap diperoleh nilai RR sebesar 1,563.

\section{BAHASAN}

\section{Pengaruh status kecemasan terhadap lama rawat inap}

Rata-rata skor kecemasan subjek penelitian sebesar 8,77 (SD $\pm 3,62)$. Penelitian menunjukkan bahwa skor kecemasan subjek penelitian secara umum masih berada pada level yang baik. Hal ini ditunjukkan dengan rata-rata skor kecemasan semua subjek penelitian $<11$, yang merupakan batas seseorang dikatakan cemas. Kecemasan dapat dipengaruhi oleh beberapa faktor, yaitu: usia, pengalaman menjalani pengobatan, konsep diri, tingkat pendidikan, diagnosa penyakit, akses informasi, proses adaptasi, tingkat sosial ekonomi, dan komunikasi terapeutik (8).

Tabel 5 menunjukkan rata-rata lama rawat inap pasien yang cemas dan tidak cemas, nilai tersebut masing-masing adalah 4,74 dan 3,51 hari. Antara pasien cemas dan tidak cemas tersebut ada perbedaan sebesar 1,23 hari. Perbedaan ini dapat membuktikan bahwa di antara kedua kelompok tersebut memiliki lama rawat inap yang berbeda karena nilai $p$ yang diperoleh berdasarkan uji statistik sebesar 0,001 $(p<0,05)$. Hal ini menunjukkan bahwa ada pengaruh antara status kecemasan terhadap lama rawat inap. Begitupula dengan hasil uji chisquare yang menunjukkan adanya hubungan antara status kecemasan dengan lama rawat inap yang ditunjukkan dengan nilai $p=0,001(p<0,05)$ (Tabel 6).
Berdasarkan hasil uji regresi logistik antara variabel status kecemasan dengan lama rawat inap diperoleh nilai RR sebesar 2,385. Hal ini berarti bahwa pasien jantung dengan kecemasan memiliki kemungkinan lama rawat 2,385 kali lebih panjang daripada pasien jantung tanpa kecemasan.

Pada penelitian sebelumnya menyebutkan bahwa korelasi antara depresi terhadap lama rawat inap pasien bedah torak di rumah sakit $(r=0,492$, $p<0,05)$. Penelitian ini juga menyatakan bahwa pasien yang depresi pada saat masuk memiliki lama rawat yang lebih panjang daripada pasien yang tidak depresi (9). Sebagaimana diketahui bahwa kecemasan merupakan salah satu gejala dari depresi, seperti fisiologikal, sosial, psikologikal, hingga dalam penanganan pasien. Lebih jauh gangguan kecemasan ini dapat berakibat tidak baik pada kualitas hidup penderita jantung (4) yang pada akhirnya juga dapat memperparah penyakit pasien yang ditandai oleh kejadian masuk rumah sakit yang berulang, peningkatan insiden iskemik penderita, dan juga mortalitas pasien jantung (10).

Salah satu faktor psikologi yang dapat mempengaruhi kecemasan adalah perasaan optimis. Perasaan optimis yang tinggi secara positif berhubungan dengan strategi koping seseorang dalam menghadapi suatu permasalahan. Faktor lain yang mempengaruhi kecemasan ini yaitu dukungan sosial. Dukungan sosial yang baik dari lingkungan sekitar seseorang merupakan faktor protektif bagi seseorang yang memiliki banyak permasalahan dan kecemasan yang tinggi. Dukungan sosial dapat meningkatkan kebahagiaan seseorang yang tentu memiliki implikasi terhadap faktor psikologis 
seseorang (11) sehingga mengurangi lama rawat inap pasien yang dirawat di rumah sakit.

\section{Pengaruh status gizi terhadap lama rawat}

Hasil rata-rata LLA subjek penelitian sebesar $26,17 \mathrm{~cm}(\mathrm{SD} \pm 4,53)$. Hasil tersebut menunjukkan bahwa status gizi subjek penelitian cukup baik. Hal ini berlaku baik untuk subjek laki-laki maupun perempuan karena pengukuran LLA berada di atas ambang batas penilaian status gizi yang baik untuk semua jenis kelamin.

Tabel 5 menunjukkan hasil rata-rata lama rawat inap pasien dengan status gizi baik dan kurang, masing-masing adalah 3,79 dan 4,53 hari. Ada perbedaan sebesar 0,74 hari. Perbedaan ini dapat membuktikan bahwa di antara kedua kelompok yaitu kelompok status gizi baik dan kelompok status gizi kurang memiliki lama rawat inap yang berbeda karena nilai p yang diperoleh berdasarkan uji statistik sebesar $0,044(p<0,05)$. Begitupula dengan hasil uji chi-square yang menunjukkan adanya hubungan antara status gizi dengan lama rawat inap dengan nilai $p=0,015$ $(p<0,05)$. Hal ini menunjukkan bahwa ada pengaruh antara status gizi terhadap lama rawat inap. Dari hasil analisis regresi logistik, hasilnya menunjukkan bahwa status gizi dan lama rawat inap memiliki hubungan yang bermakna yang ditandai dengan nilai $p<0,05$ (Tabel 2), sedangkan untuk nilai $R R=1,563$ yang berarti bahwa pasien jantung dengan status gizi kurang memiliki kemungkinan lama rawat inap 1,563 kali lebih panjang dari pada pasien jantung dengan status gizi baik.

Hasil ini sesuai dengan penelitian sebelumnya yang menunjukkan bahwa subjek penelitian yang berstatus gizi dari baik menjadi sedang, baik menjadi buruk, dan sedang menjadi buruk berturut-turut memiliki selisih lama rawat 3 hari, 8 hari, dan 6 hari. Pasien dengan status gizi menurun mempunyai ratarata lama rawat inap 14 hari, sedangkan pasien yang status gizinya meningkat dan tetap memiliki rata-rata lama rawat inap 10 hari. Berdasarkan hasil tersebut, dapat diketahui bahwa pasien dengan status gizi meningkat dan tetap memiliki lama rawat yang lebih pendek dibandingkan dengan pasien dengan status gizi menurun (7). Pada penelitian lain menunjukkan bahwa pasien dengan penurunan status gizi selama dirawat memiliki lama rawat inap yang lebih panjang dibandingkan dengan pasien yang tidak mengalami penurunan status gizi. Penurunan status gizi memiliki rata-rata lama rawat 9,6 hari, sedangkan untuk pasien yang tidak mengalami penurunan status gizi memiliki rata-rata 7,6 hari atau ada selisih 2 hari rawat antara kedua kelompok tersebut. Secara statistik, hasil analisis yang diperoleh adalah bermakna (12).

Pasien yang berisiko malnutrisi mempunyai masa rawat yang lebih panjang daripada yang tidak berisiko malnutrisi (13). Hal ini berkaitan dengan kondisi pasien, yaitu adanya penyakit kronis yang diderita seperti anoreksia akan menyebabkan penurunan asupan makanan dan penyebab terjadinya malnutrisi kurang energi protein. Malnutrisi ini dapat meningkatkan disfungsi gastrointestinal, karena infeksi dan penyembuhan luka yang akan menimbulkan malnutrisi dan bertambah buruknya asupan makanan. Beberapa kejadian lain, seperti sepsis dan pneumonia, dapat menyebabkan hipermetabolisme dan gangguan inflamatori serta mempengaruhi katabolisme. Katabolisme juga dapat menyebabkan disfungsi gastrointestinal, infeksi, dan memperlambat penyembuhan luka, yang dapat menurunkan asupan makan dan menjadi penyebab malnutrisi kurang energi protein. Kedua kondisi akut dan kronis tersebut dapat berinteraksi sinergis terhadap status gizi pasien dan menyebabkan malnutrisi secara progresif dan memperpanjang lama rawat inap pasien (14).

Peningkatan insiden malnutrisi pada pasienpasien di rumah sakit akan meningkatkan lama rawat inap dan biaya perawatan sehingga diperlukan pemberian intervensi gizi sedini mungkin. Upaya ini dapat dilakukan dengan mengidentifikasi pasienpasien yang memiliki risiko malnutrisi dan tidak berisiko malnutrisi untuk kemudian diberikan tindakan pencegahan yang lebih dini (15).

\section{KESIMPULAN DAN SARAN}

Hasil penelitian ini menunjukkan bahwa terdapat pengaruh status kecemasan terhadap lama rawat inap pada pasien jantung. Pasien jantung dengan kecemasan memiliki kemungkinan lama rawat inap yang lebih panjang daripada pasien jantung tanpa kecemasan. Terdapat pengaruh status gizi terhadap 
lama rawat inap pada pasien jantung. Pasien jantung dengan status gizi kurang memiliki kemungkinan lama rawat inap yang lebih panjang daripada pasien jantung dengan status gizi baik.

Rekomendasi yang dapat diberikan yaitu perlu adanya penelitian lebih lanjut mengenai status kecemasan terhadap lama rawat inap pasien dan faktor-faktor lain yang mempengaruhinya. Perlu dilakukannya asessmen mengenai status kecemasan bagi pasien saat masuk rumah sakit sebagai salah satu pelayanan dari rumah sakit, khususnya pada pasien penyakit jantung.

\section{RUJUKAN}

1. Konstam V, Moser D, De Jong M. Review articles: depression and anxiety in heart failure. J Card Fail. 2005;11(6):455-63.

2. De Jong $M$, Chung $M$, Wu J, Riegel $B$, Rayens $M$, Moser D. Linkages between anxiety and outcomes in heart failure. Hear Lung. 40AD;5(393-404).

3. Darmo W. Tingkat kecemasan pada penderita gagal jantung di RSUP Dr. Sardjito Yogyakarta. Universitas Gadjah Mada; 1995.

4. Yohannes A, Willgoss T, Baldwin R, Connolly M. Review article: depression and anxiety in chronic heart failure and chronic obstructive pulmonary disease: prevalence, relevance, clinical implications and management principles. Int J Geriatr Psychiatry. 2010;25:1209-21.

5. Roest A, Martens E, de Jonge P, Denollet J. Anxiety and risk of incident coronary heart disease. J Am Coll Cardiol. 2010;56(1):38-46.

6. Rekam medis RSUD Jend. A.Yani Metro. Laporan kegiatan RSUD Jend. A.Yani Metro. Metro: RSUD Jend. A.Yani Metro; 2014.
7. Budiningsari R. Pengaruh perubahan status gizi pasien dewasa terhadap lama rawat inap dan biaya rumah sakit. Universitas Gadjah Mada; 2003.

8. Kaplan H, Sadock B. Comprehensive textbook of psychiatry, 6th edition. Philadelphia: Lippincott Williams \& Wilkins; 1995.

9. Kitagawa R, Yasui-Furukori N, Tsushima T, Kaneko S, Fukuda I. Depression increases the length of hospitalization for patients undergoing thoracic surgery : a preliminary study. Acad Psychosom Med. 2011;52:42832.

10. Januzzi J, Stern T, Pasternak R, DeSanctis $R$. Review article: the influence of anxiety and depression on outcomes of patients with coronary artery disease. Arch Intern Med. 2000;160:1913-31.

11. Wang Q, Hay M, Clarke D, Menahem S. The prevalence and predictors of anxiety and depression in adolescents with heart failure. $\mathrm{J}$ Pediatr. 2012;161:943-6.

12. Handini K. Pengaruh penurunan status gizi terhadap lama rawat inap dan status pulang pasien dewasa di RSUP Dr. Sardjito Yogyakarta. Universitas Gadjah Mada; 2010.

13. Chima C, Barco K, Dewitt M, Maeda M, Teran $\mathrm{J}$, Mullen K. Relationship of nutritional status to length of stay, hospital costs, and discharge status of patients hospitalized in the medicine service. J Am Diet Assoc. 1997;97:975-8.

14. Kyle U, Coss-Bu J. Nutritional asessment and length of hospital stay. Can Med Assoc J. 2010;182:1831-2.

15. Yanti F. Status gizi awal masuk pasien dewasa sebagai prediktor lama rawat inap di rumah sakit. Universitas Gadjah Mada; 2003. 